\title{
Research skills and ethics: the 20 -year evolution of a professional development graduate course
}

\author{
Penny J. Beuning ${ }^{1}$
}

Published online: 29 October 2016

(C) Springer-Verlag Berlin Heidelberg 2016

\section{Introduction}

Professional societies, agencies, and others agree on the need to improve the professional development of graduate students in the sciences [1-3]. Since the mid-1990s, the Department of Chemistry and Chemical Biology at Northeastern University has offered a required course in Research Skills and Ethics in Chemistry. This course has undergone refinement over the years to address the changing needs of our students as well as structural changes to our Ph.D. program. This article will discuss the topics covered, the current format of the course, and some key aspects of its evolution.

Concerned that entering graduate students need to be oriented with respect to their degree program, its requirements, and the resources and personnel available to assist them, and recognizing the skills and tasks specific to the conduct of scientific research, a new required course entitled "Research Skills and Ethics" was added to the doctoral degree program in chemistry in 1995, which was taught by Professor Patricia Ann Mabrouk until 2003 [4]. In the beginning, full-time doctoral students completing their first year of study took the course during the summer quarter, which was appropriate because first-year students identified their dissertation advisors during the spring quarter. Thus, at the start of the summer quarter, the first-year graduate students were beginning their full-time research. In the original course, students explored a number of issues, including laboratory safety and waste disposal, and skills specific to the conduct of research in

Penny J. Beuning

p.beuning@neu.edu

1 Department of Chemistry and Chemical Biology, Northeastern University, 360 Huntington Avenue, Boston, MA 02115, USA chemistry, including literature searching, record keeping, experimental design, grant writing, principles of effective poster and oral presentation design and delivery, and how to read and write a technical paper. These topics have been largely retained over the years. A number of the lectures were copresented with local experts representing relevant offices and departments on campus in order to reinforce the existence of these resources and to help students get to know the individuals personally. As Northeastern is a cooperative educational institution, core competencies were also discussed in relation to different potential career paths. The course was infused from start to finish with a discussion of ethical issues as they related to the subjects being discussed that week. The course later transitioned to being taught in the spring semester of the first year for Ph.D. students.

In 2007 when we began a reform of our graduate curriculum, one of the first changes was to return Research Skills and Ethics to the summer, holding it as a summer I (May and June) course, after two semesters of full-time coursework for Ph.D. students. After several years of this schedule, it became clear that some material was coming too late in the year for maximum usefulness. Thus, the course schedule was modified so that material is presented throughout the first year, beginning during the department orientation for new Ph.D. students, and culminating in approximately one-half to two-thirds of the course being taught in the summer after the first year. For example, time management, using scientific literature, and choosing an advisor are discussed early in the year. After new student orientation, the course meets in open colloquium and seminar times throughout the year, and then two evenings per week in May and June, as our graduate courses are typically evening classes.

The major foci of the class are acculturation into our program and as practicing scientists, development of communication skills, and in-depth discussion of case studies to 
develop ethical reasoning skills [5]. The responsible conduct of research is discussed in depth over several class meetings and this and other ethical issues are woven into discussion of other topics throughout the course. The textbooks are "Tools for Success in Science: A Chicago Guide for Graduate Students and Postdoctorals" [6], "Scientific Integrity" [5], "The ACS Style Guide" [7], "Scientific Papers and Presentations" [8], and "On Being a Scientist: A Guide to Responsible Conduct in Research" [9]. "How to Write and Publish a Scientific Paper" [10] is an optional text and "Writing the Laboratory Notebook" [11] is available as a reference. Our university library offers several of these books electronically, which minimizes student expenses. The topics in the course are discussed in some detail below.

\section{Research skills and the responsible conduct of research}

A major portion of the class is dedicated to discussion of responsible conduct of research, which begins with definitions of misconduct and federal offices that have jurisdiction over research misconduct. I emphasize that the goal of practicing scientists should always be to carry out research responsibly, not just to avoid misconduct. The class as a whole discusses examples of plagiarized text and habits to develop in order to avoid plagiarism. Most college and university writing centers have excellent materials on plagiarism that can be adopted for classroom use; we use a combination of local resources and those from the Indiana University, Bloomington Writing Tutorial Services [12]. We examine manipulated data, discuss acceptable adjustments to images, the difference between technical and experimental replicates, and address other issues of experimental design [13-16]. In addition to examples from published papers that provide examples of data manipulation $[15,16]$, examples from the Office of Research Integrity, which publishes case findings, are also highlighted [17]. Record keeping and maintaining laboratory notebooks are also discussed.

The pressures and motivations that can lead someone to commit misconduct are discussed, as are strategies to mitigate those pressures, and the potential consequences of misconduct [18-20]. Specific university experts are invited to discuss such topics as research with animal and human subjects; environmental health and safety; intellectual property, patents, and licensing; and obtaining funding for research.

\section{Communication skills}

Many students come to graduate school with little experience in professional communication. One goal of this class is to improve communication skills of students in speaking and writing. Therefore, there are many opportunities for feedback, first on short written assignments and then in a peer review exercise for the research proposal assignment, as outlined below. Common science writing problems are discussed as a class and we work through example sentences to improve them. Students also gain experience in speaking, including discussion of case studies, to which all students are expected to contribute. The class culminates in a presentation of a research proposal, for which students are prepared with in-depth discussion of effective presentation skills and design of visual materials. Related to this topic is a discussion of attending and presenting research at conferences and discussion of inherent ethical issues, such as what to do when the work described as "in progress" in an abstract does not come to fruition by the time of the conference, how to share credit clearly in presentations, disclosing conflicts of interest, and the fairly common prohibition against recording or citing conference presentations.

The course also addresses using the scientific literature effectively, including designing literature searches and searching the patent literature. Scientific publishing and peer review are discussed, including the attendant ethical issues, such as authorship, confidentiality, and conflict of interest. One very popular case study discussed in class asks students to decide, from a list of people and their contributions to a project, who should be included as an author and who should be acknowledged, and if any of the individuals should be given no credit ("Criteria for Authorship and Attribution: Bob Powell" [21]).

\section{Working with others}

Actual or perceived conflicts with others are a major source of stress for graduate students [22]. The Research Skills and Ethics class includes an in-depth discussion of choosing an advisor and effectively working with one's advisor, as well as a discussion of general strategies to deal with conflict. This discussion draws heavily from a program developed at Michigan State University to address this issue, which incorporates the approach of interest-based conflict resolution [22-24].

\section{Career development}

Encouraging students to begin considering their career options early is important for their professional development. This class includes a panel discussion, which is open to the entire department, with professionals from a variety of chemistryrelated fields. It is a goal of mine to include alumni from our program on this panel whenever possible. Panelists have included liberal arts college and/or comprehensive university 
faculty, scientists and technical specialists in biotechnology or pharmaceutical companies, science writers, journal editors, art restoration specialists, science museum curators, directors of outreach or education, industrial postdoctoral researchers, intellectual property attorneys and licensing agents, and science policy specialists. After the panel, the remainder of the class is dedicated to identifying skills and interests to inform one's choice of career, writing effective cover letters, resumes or $\mathrm{CVs}$, and applying and interviewing for jobs. Individual development plans (IDP) are introduced and students are encouraged to use an IDP on an on-going basis. A brief writing exercise encourages students to reflect on rewarding experiences in research and otherwise, as well as to consider more and less desirable aspects of their future careers; we discuss answers in class, highlighting how to use these insights in career planning. The careers discussion includes ethical issues encountered during this process, including the importance of accuracy in application materials, how to represent accurately one's contributions to collaborative projects during interviews, as well as how to handle inappropriate interview questions. We discuss the consequences of misrepresentation during this process using actual news stories [25, 26].

\section{Case studies}

The course makes extensive use of case studies throughout the year to encourage student participation in discussion of ethical issues and development of ethical reasoning. At the beginning of the course, we outline how to discuss case studies, including identifying all interested parties, their interests, possible courses of action, and best courses of action. Students are reminded to focus on identifying solutions. At the end of each case, or set of cases, we "rewind" and ask how the current conflict situation could have been avoided, which focuses attention on putting systems in place to foster responsible conduct. Providing this framework for case discussions helps give all students the same background for these discussions, regardless of prior experience.

In general, case studies relevant to the topic of the class are discussed during every class period. The specific style varies by class and by case: some cases are performed as short plays with students reading specific parts; the students read cases in advance and come to class to discuss the case, in these instances we always begin with reading the case aloud again to refresh memories and then recap the main points; short cases are read aloud by a student and then discussed; or several short cases are discussed in small groups and then each group presents its case to the class; in this instance I circulate through the class during the small group discussions to check on the groups and provide prompts or answer questions when necessary. There are numerous excellent sources for case studies, and a few are referenced here $[5,9,21]$. In addition, the course draws on misconduct cases that have been reported in the media, for example [15, 27-29]. In one example, several cases relate to ownership of data, materials, and specifically, laboratory notebooks ("Jessica Banks," "The Sharing of Research Materials" [9, 30]). After students discuss the issues and the range of possible solutions in each case; we discuss policies on data and materials ownership in their own research groups, their prior employment, and the University policies on these issues.

\section{Assignments and grading}

Grading is based on class participation, a series of short papers, a written and oral presentation of a research proposal, and a cover letter, curriculum vitae, and LinkedIn profile. The schedule is such that several short papers are due well before the first draft of the proposal in order to identify problems with writing early and provide students the opportunity to correct them. Detailed feedback is provided on each assignment in terms of both coherent and technically correct writing. In addition, several short assignments provide the opportunity to build the foundation for the research proposal. For example, one short paper asks the students to choose a paper from the primary research literature, summarize the paper, and then suggest one or two additional experiments and future work that builds on the paper. Students are asked to discuss relevant controls and expected outcomes. Another assignment requires students to submit an annotated bibliography of references related to their proposals. The proposal is submitted as a draft, with students then engaging in peer review [31], and the final proposal is due after the final presentations. Students can then use feedback from the peer review as well as from their presentations to polish their final proposals. Ph.D. students are required to choose an advisor at the end of the second semester and the proposals are due two months later, so the proposal assignment provides an incentive for students to delve into the literature and propose a project relevant to their dissertation research. Other short writing assignments include reflective writing pieces about criteria for authorship and working effectively with one's advisor. The final assignment is a cover letter, $\mathrm{CV}$, and LinkedIn profile. Feedback from prospective employers indicates that many students have LinkedIn profiles that are incomplete or contain irrelevant information; therefore, part of the Career Development assignment is to submit an updated LinkedIn profile for feedback. Enrollment in this class in the last approximately 10 years is typically between 15 and 20 students. Grading and providing feedback on the written assignments is a major part of instructor time for this course. However, most students appreciate both the detailed feedback and the scaffolding of the research proposal assignment as revealed by student comments in the university course evaluations. 


\section{Summary}

Education in the responsible conduct of research is critical for the professional development of science students. This report describes a course that makes extensive use of fictional and real case studies to develop the ability to identify ethical issues and possible solutions in a given scenario. This course also provides multiple opportunities for students to receive feedback on their communication skills. Furthermore, because this class is taught early in the graduate curriculum, it is positioned to prepare students for success in their graduate research.

Acknowledgments The recent development of this course was supported by NSF CAREER Award MCB-0845033 to P.J.B. and a Cottrell Scholar Award from Research Corporation for Science Advancement to P.J.B. The numerous guest speakers who have generously contributed to this class are gratefully acknowledged. The author is grateful to Professor Patricia A. (Pam) Mabrouk for her support in the transition of the course and for critically reading this manuscript.

\section{References}

1. LaPidus JB, Mishkin B. Values and ethics in the graduate education of scientists. In: May WW, editor. Ethics and higher education. New York: American Council on Education; 1990. p. 398.

2. American Chemical Society. Advancing graduate education in the chemical sciences. Washington, DC; 2012.

3. Tachibana C. Responsibly conducting research. Science. 2016. doi:10.1126/science.opms.r1600161.

4. Mabrouk PA. Research skills and ethics - a graduate course empowering graduate students for productive research careers in graduate school and beyond. J Chem Educ. 2001;78:1628-31.

5. Macrina FL. Scientific integrity. 3rd ed. Washington, DC: ASM Press; 2005.

6. Bloomfield V, El-Fakahany E. Tools for success in science: a Chicago guide for graduate students and postdoctorals. Chicago: University of Chicago Press; 2008.

7. Coghill AM, Garson LR, editors. The ACS style guide. 3rd ed. Washington, DC: American Chemical Society; 2006.

8. Davis M. Scientific papers and presentations. San Diego: Academic Press; 1997.

9. Committee on Science, Engineering, and Public Policy. On being a scientist: a guide to responsible conduct in research. 3rd ed. Washington, DC: National Academy Press; 2009.

10. Day RA, Gastel B. How to write and publish a scientific paper. 7th ed. Philadelphia: Greenwood; 2011.

11. Kanare HM. Writing the laboratory notebook. Washington, DC: American Chemical Society; 1985.

12. Indiana University B Writing Tutorial Services. Plagiarism: what it is and how to recognize and avoid it. Available from: http://www. indiana.edu/ wts/pamphlets/plagiarism.shtml\#original. Accessed: September 5, 2016.

13. Couzin J. Scientific publishing. don't pretty up that picture just yet. Science. 2006;314:1866-8.
14. Young JR. Journals find fakery in many images submitted to support research in chronicle of higher education. 2008.

15. Anumolu R, Gustafson JA, Magda JJ, Cappello J, Ghandehari H, Pease III LF. Retraction of fabrication of highly uniform nanoparticles from recombinant silk-elastin-like protein polymers for therapeutic agent delivery. ACS Nano. 2014;8:11899.

16. Rossner M, Yamada KM. What's in a picture? The temptation of image manipulation. J Cell Biol. 2004;166:11-5.

17. United States Department of Health and Human Services Office of Research Integrity. Case summaries. Available at: http://ori.hhs. gov/case_summary. Accessed 5 September 2016.

18. Cohen J. Intellectual property. dispute over lab notebooks lands researcher in jail. Science. 2011;334:1189-90.

19. Kintisch E. Poehlman sentenced to 1 year of prison. Science. 2006.

20. Samuel Reich E. Biologist spared jail for grant fraud. Nature. 2011;474:552.

21. Korenman SG, Shipp AC. Teaching the responsible conduct of research through a case study approach: a handbook for instructors. Washington, DC: Association of American Medical Colleges; 1994.

22. Klomparens KL, Beck JP. Building mutuality and resolving conflicts between graduate students and faculty: a proactive approach. WISE Best Practices Guidebook: The Classroom. 1997.

23. Fisher R, Patton BM, Ury WL. In: Patton BM, editor. Getting to yes: negotiating agreement without giving. New York: Houghton Mifflin; 1981

24. Ury WL. Getting past no. New York: Banta; 1991.

25. Bombardieri M. Ex-MIT dean never cited actual degree, in The Boston Globe. 2007.

26. Jacobs DL. The high price of career lies, in Forbes. 2012.

27. Holden C. Korean stem cell scandal. Schatten: Pitt panel finds 'misbehavior' but not misconduct. Science. 2006;311:928.

28. Reich ES. Biologist spared jail for grant fraud. Nature. 2011;474: 552 .

29. Trager R. Grad student blamed for research misconduct at Utah, in Chemistry World. 2014.

30. Bebeau MJ, Pimple KD, Muskavitch KMT, Borden S, Smith DH. Moral reasoning in scientific research: cases for teaching and assessment, developed for project entitled "Teaching Research Ethics: a workshop at Indiana University,” pp. 21-29, Indiana University. 1995.

31. Patterson RL. Instructing graduate students to tackle the "real world": a course description. Sci STKE. 2007;394:tr3.

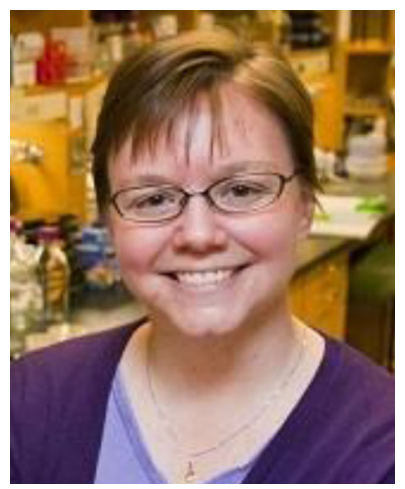

Penny J. Beuning is Associate Professor of Chemistry and Chemical Biology at Northeastern University. She is involved in teaching in chemical biology and in responsible conduct of research; her mentoring efforts include professional development of science students and faculty. Her research interests are in DNA replication and mutagenesis, protein dynamics, and protein engineering. 